This article was downloaded by: [New York University]

On: 18 April 2015, At: 07:36

Publisher: Routledge

Informa Ltd Registered in England and Wales Registered Number: 1072954

Registered office: Mortimer House, 37-41 Mortimer Street, London W1T

3J H, UK

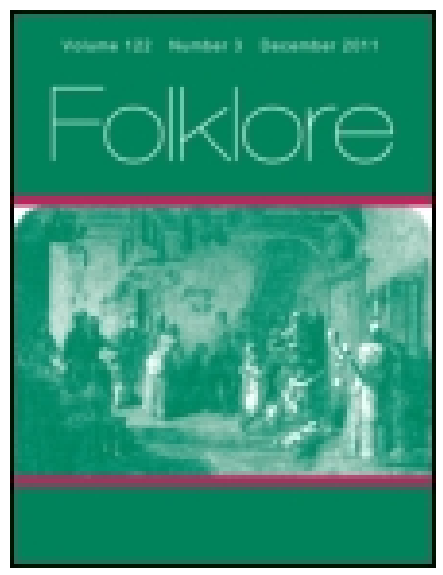

\title{
Folklore
}

Publication details, including instructions for authors and subscription information:

http:// www. tandfonline.com/loi/ rfol20

\section{Peeping Tom and Lady Godiva}

\section{E. Sidney Hartland}

Published online: 14 Feb 2012.

To cite this article: E. Sidney Hartland (1890) Peeping Tom and Lady Godiva, Folklore, 1:2, 207-226, DOI: 10.1080/ 0015587X.1890.9720007

To link to this article: http:// dx. doi. org/ 10.1080/0015587X.1890.9720007

\section{PLEASE SCROLL DOWN FOR ARTICLE}

Taylor \& Francis makes every effort to ensure the accuracy of all the information (the "Content") contained in the publications on our platform. However, Taylor \& Francis, our agents, and our licensors make no representations or warranties whatsoever as to the accuracy, completeness, or suitability for any purpose of the Content. Any opinions and views expressed in this publication are the opinions and views of the authors, and are not the views of or endorsed by Taylor \& Francis. The accuracy of the Content should not be relied upon and should be independently verified with primary sources of information. Taylor and Francis shall not be liable for any losses, actions, claims, proceedings, demands, costs, expenses, damages, and other liabilities whatsoever or howsoever caused arising directly or indirectly in connection with, in relation to or arising out of the use of the Content.

This article may be used for research, teaching, and private study purposes. Any substantial or systematic reproduction, redistribution, reselling, loan, sub-licensing, systematic supply, or distribution in any form to anyone is 
expressly forbidden. Terms $\&$ Conditions of access and use can be found at http://www.tandfonline.com/page/terms-and-conditions 


\section{PEEPING TOM AND LADY GODIVA.}

$\mathrm{N}$ an article which appeared in one of the later numlength the stories of midwives who have assisted lady fairies in the hour of their need. The chief points of interest were the necessity for human help, the danger of accepting fairy food, the gratitude of these supernatural beings, and the conditions involved in the acceptance of their gifts. There remains, however, another class of tale similar in its general tenor to these, but wherein we are led by a new turning-point to a different catastrophe. The plot no longer hinges upon fairy gratitude, but upon human curiosity and disobedience.

The typical tale is told, and exceedingly well toldthough, alas I not exactly in the language of the nativesby Mrs. Bray in her Letters to Southey, of a certain midwife of Tavistock. One midnight, as she was getting into bed, this good woman was summoned by a strange, squinteyed, little, ugly old fellow to follow him straightway, and attend upon his wife. In spite of her instinctive repulsion she could not resist the command; and in a moment the little man whisked her, with himself, upon a large coal-black horse with eyes of fire, which stood waiting at the door. Ere long she found herself at the door of a neat cottage ; the patient was'a decent-looking woman who already had two children, and all things were prepared for her visit. When the child-a fine, bouncing babe-was born; its mother gave the midwife some ointment, with directions to "strike the child's eyes with it". Now the word strike in the Devonshire dialect means not to give a blow, but to rub, or touch, gently; and as the woman obeyed she thought 


\section{8}

Peeping Tom and Lady Godiva.

the task an odd one, and in her curiosity tried the effect of the ointment upon one of her own eyes. At once a change was wrought in the appearance of everything around her. The new mother appeared no longer as a homely cottager, but a beautiful lady attired in white; the babe, fairer than before, but still witnessing with the elvish cast of its eye to its paternity, was wrapped in swaddling clothes of silvery gauze; while the elder children, who sat on either side of the bed, were transformed into flat-nosed imps, who with mops and mows were busied to no end in scratching their own polls, or in pulling the fairy lady's ears with their long and hairy paws. The nurse, discreetly silent about what she had done and the wonderful metamorphoses she beheld around her, got away from the house of enchantment as quickly as she could; and the sour-looking old fellow who had brought her carried her back on his steed much faster than they had come. But the next market-day, when she sallied forth to sell her eggs, whom should she see bit the same ill-looking scoundrel busied in pilfering sundry articles from stall to stall. So she went up to him, and with a nonchalant air addressed him, inquiring after his. wife and child, who, she hoped, were both as well as could be expected. "What !" exclaimed the old pixy thief, "do you see me to-day?" "See you ! to be sure I do, as plain as I see the sun in the skies; and I see you are busy into the bargain," she replied. "Do you so ?" cried he ; "pray, with which eye do you see all this ?" " With the right eye, to be sure." "The ointment ! the ointment l" exclaimed the old fellow; "take that for meddling with what did not belong to you : you shall see me no more." He struck her eye as he spoke, and from that hour till the day of her death she was blind on the right side, thus dearly paying for having gratified an idle curiosity in the house of a pixy. ${ }^{\text {l }}$

The earliest writer who mentions a story of this type is Gervase of Tilbury, Marshal of the kingdom of Arles, who wrote about the beginning of the thirteenth century. He

1 Mrs. Bray, The Tamar aind the Tavy, i, 174. 
professes to have himself met with a woman of Arles, who was one day washing clothes on the banks of the Rhone, when a wooden bowl floated by her. In trying to catch it she got out of her depth, and was seized by a Drac. The Dracs were beings who haunted the waters of rivers, and dwelt in the deep pools, appearing often on the banks and in the towns in human form. The woman in question was carried down beneath the stream, and made nurse to her captor's son. One day the Drac gave her an eel pasty to eat. Her fingers became greasy with the fat, and she happened to put them to one of her eyes. Forthwith she acquired a clear and distinct vision under the water. After some years she was allowed to return to her husband and family, and going early one morning to the market-place of Beaucaire, she met the Drac. Recognising him at once, she saluted him and asked after the health of his wife and child. "With which eye do you see me?" inquired the Drac. The woman pointed to the eye she had touched with the eel-fat; and thrusting his finger into it, the Drac vanished from sight.

Here the only punishment suffered is the deprivation of the power of seeing fairies, or banishment from their society. This seems mild enough : much more was generally inflicted. The story first quoted relates what seems to be the ordinary form of vengeance for disregard of the prohibition to use the fairy eye-salve, namely, loss of sight in the offending eye. Spitting or striking is usually the means adopted by the elves to effect this end. Sometimes, however, the eye is torn from its socket. Whether there is much to choose between these different ways of undergoing the punishment is doubtful ; but it should be noted that the last-mentioned mode is a favourite one in Brittany, and follows not so much on recognition as on denunciation by virtuous mortal of the elfs thieving propensities. "See what thieves these fairies are l" cried a woman who wotched one of them putting her hand into the pocket of a country VoL. I.

1 Gervase of Tilbury, Otia Imperialia, Decisio IIT, c. 85. 
woman's apron. The fairy instantly turned round and tore out her eye. "Thieves!" bawled another on a similar occasion, with the same result. ${ }^{1}$ In a Cornish tale a woman is entrusted in her own house with the care of an elf-child. The child brought remarkable prosperity to the house, and his foster-mother grew very. fond of him. Finding that a certain water in which she was required to wash his face made it very bright, she determined to try it on her own, and splashed some of it into her eye. This conferred the gift of seeing the little people, who played with her boy, but had hitherto been invisible to her; and one day she was surprised to meet her nursling's father in the market-stealing. Recognition followed, and the stranger exclaimed :

"Water for elf, not water for self, You've lost your eye, your child, and yourself."

From that hour she was blind in the right eye. When she got home the boy was gone; and she. and her husband, who had once been so happy, became poor and wretched."

Here poverty and wretchedness, as well as the loss of an eye, were inflicted. In a Northumbrian case the fosterparent lost his charge and both eyes. ${ }^{2}$ So in a story from Guernsey, the midwife, on the Saturday following her attendance on the lady, meets the husband and father in a shop filling his basket to right and left. She at once comprehends the plenty that reigned in his mysterious dwelling. "Ah, you wicked thief, I see you l" she cried. "You see me; how ?" he inquired. "With my eyes," she replied. "In that case I will soon put you out of power to play the spy," ho answered. 'So saying, he spat in her face, and she'

1 Sebillot, Contes, ii, 42 ; Litt. Orale, 23 ; Traditions it Superstitions, if rog. But in these cases the operation was performed painlessly enough, for the victims were unaware of their loss until they came to look in the glass. In one of Prof. Rhys's stories the eye is pricked with a green rush. $Y$ Cymmrodor, vi, 178.

I Hunt, 83. See also Sébillot, $i$, 119 .'

- Keightley, 3 ro. 
became blind on the spot. ${ }^{1}$ A Danish story also relates that a midwife, who had inadvertently anointed her eyes with the salve handed to her by the elf-folk for the usual purpose, was going home afterwards and passed by a ryefield. The field was swarming with elves, who were busy clipping off the ears of rye. Indignantly she cried out, "What are you doing there?" The little people thronged round her, and angrily answered: "If thou canst see us, 'thus shalt thou be served;" and suiting the action to the word, they put out her eyes.2

Human beings, however, betray their meddling with fairy ointment in other ways than by speech. The following curious story was related as current at his native place, by Dr. Carré of St. Jacut-dela-Mer, to M. Sébillot. A fisherman from St. Jacut was the last to return one evening at dusk from the scene of his labours; and as he walked along the wet sand of the seashore, he suddenly came upon a number of sea-fairies in a cavern, talking and gesticulating with vivacity, though he could not hear what they said. He beheld them rub their eyes and bodies with a sort of pomade, when, lo! their appearance changed, and they were enabled to walk away in the guise of ordinary women. Hiding carefully behind a large rock, he watched them out of sight; and then, impelled by curiosity, he made straight for the cave. There he found what was left of the pomade, and taking a little on his finger, he smeared it around his left eye. By this means he found himself able to penetrate the various disguises assumed by the fairies for the purpose of robbing or annoying mankind. He recognised as one of that mischievous race a beggar-woman whom he saw a few days afterwards going from door to door demanding charity. He saw her casting spells on certain houses, and peering eagerly into all, as if she were

\footnotetext{
1 Revue des Trad. Pap., iii, 426.

1 Thorpe, ii, 129, quoting Thiele. In another Danish tale given on the same page, the woman's blindness is attributed to her having divolged what she had seen in Fairyland.
} 
sccking for something to steal. He distinguished, too, when out in his boat, fish which were real fish from fish which were in reality "ladies of the sea", employed in entangling the nets and playing other tricks upon the seamen. Attending the fair of Ploubalay, he saw several elves who had assumed the shapes of fortune-tellers, showmen, or gamblers, to deceive the country folk; and this permitted him to keep clear of their temptations. But as he smiled to himself at what was going on around him, some of the clves, who were exhibiting themselves on a platform in front of one of the booths, caught sight of him ; and he saw by the anger in their looks that they had divined his secret. Before he had time to fly, one of them, with the rapidity of an arrow, struck his clairvoyant eye with a stick and burst it. That is what happened to him who would learn the secrets of the sea-fairies. 1

Such was the punishment of curiosity ; nor is it by fairies alone that curiosity is punished. Cranmere Pool on Dartmoor is; we are told, a great penal settlement for refractory spirits. Many of the former inhabitants of the parish are supposed to be still there expiating their ghostly pranks. Of the spirit of one old farmer it is related that it took seven clergymen to secure him. They, however, succeeded at last in transferring him into a colt, which was given in charge to a servant-boy with directions to take him to Cranmere Pool, and there on the brink of the pool to slip off the halter and return instantly without looking round. He did look round, in spite of the warning, and beheld the colt in the form of a ball of fire plunge into the water. But as the mysterious beast plunged he gave the lad a parting kick, which knocked out one of his eyes, just as the Calender was deprived of his eye in the Arabian Nights. Still worse was the fate that overtook a woman, who, at midnight on New Year's Eve, when all water is turned into wine, was foolhardy enough to go to a well. As she bent over it to draw, one came and plucked out her eyc, paying:

1 Sébillot, Litt. Orale, 24. 
"All water is wine, And thy two eyes are mine."

A variant of the story relates that the woman herself disappeared, and gives the rhyme as

" All water is wine, And what is thereby is mine."

It is thus obviously a common belief that supernatural beings, without distinction, dislike being watched, and are only willing to be manifested to humanity at their own pleasure and for their own purposes. In the stories of the magical ointment it is not so much the theft as the contravention of the implicit prohibition against prying into fairy business that rouses elfin anger. This will appear more clearly from the fuller consideration of cases like those mentioned in the last paragraph, in which punishment follows directly upon the act of spying. In Northamptonshire, we learn that a man whose house was frequented by fairies, and who had received many favours from them, became smitten with a violent desire to behold his invisible benefactors. Accordingly, he one night stationed himself behind a knot in the door, which divided the living-room of his cottage from the sleepingapartment. True to their custom, the elves came to disport themselves on his carefully-swept hearth, and to render to the household their usual good offices. But no sooner had the man glanced upon them than he became blind; and so provoked were the fairies at this breach of hospitality that they deserted his dwelling, and never more returned to it." In Southern Germany and Switzerland, a mysterious lady known as Dame Berchta is reputed to be abroad on Twelfth Night. She is doubtless the relic of a heathen goddess, one of whose attributes was to be a leader of the souls of the dead, and as such she is followed by a band of

1 "Choice Notes," Folk-Lore, 170; Thorpe, Northern Mytho$\log y, \mathrm{iii}, 8$.

2 Sternberg, 132. See also Thorpe, op. cit., ii, 12. 


\section{Peeping Tom and Lady Godiva.}

children. For her the peasants on Twelfth Night set a repast, of which, if she be pleased, she and her troop partake. A servant boy at a peasant's farm in the Tyrol on one such occasion perceived Lady Berchta's approach, and hid himself behind the kncading-trough to watch what she would do. She immediately became aware of his presence as he peeped through a chink, and called to onc of her children to go and stop that chink. The child went and blew into it, and the boy became stark-blind. Thus he continued for a year, nor could any doctor help him, until an old experienced man advised him to go to the same place on the following Twelfth-tide, and, falling down on his knees behind the kneading-trough, to bewail his curiosity. He accordingly did so. Dame Berchta came again, and taking pity on him, commanded one of her children to restore his sight The child went and blew once more through the chink, and the boy saw. Berchta, however, and her weird troop he saw not; but the food set out for them had disappeared.

The tradition of the goddess Hertha lingered until recently, and perchance lingers still, in the island of Rigen. She had her dwelling, it is believed, in the Herthaburg; and often yet, in the clear moonlight, out of the forest which enfolds that hill, a fair lady comes surrounded by her maids to bathe in the lake at its foot. After awhile they emerge from the waters, and, wrapt again in their long white veils, they vanish flickering among the trees. But to the belated wanderer, if any such there be, who looks upon this scene, it is a vision of dread ; for he is drawn by irresistible might to the lake wherein the white lady is bathing, to be swallowed up in its depths. And it is said that every year the lady must lure one unhappy mortal into the flood.2 So in the classic mythology, if Ovid report aright,

1 Von Alpenberg, 63. - See a similar story in Grimm's Teut. Mythology, 276, from Börner's "Folk-tales of the Orlagau". In the latter case, howeyer, the punishment seems to have been inflicted for jeering.

I Jahn, 177, quoting. Temme's Volkssager. 
Actæon met the fearful fate of transformation into a stag by "gazing on divinity disrobed", and was torn in pieces by his own hounds. Hertha was, indeed, according to Tacitus, more terrible than Diana, since death was the penalty even when duty called her slaves to the awful sight.

These traditions lead us naturally to the legend of Lady Godiva As generally told to-day, that legend bears an unmistakable resemblance to the foregoing stories; but there seems some difficulty in classing it with them, because Peeping Tom is wanting in the most ancient version known to us.

Godiva, properly Godgifu, was an undoubted historical personage, the wife of Leofric, Earl of the Mercians, and mother of the Earls Morcar and Edwin, and of Edith, wife first of Gruffydd, Prince of North Wales, and afterwards of King Harold the Second. The earliest mention of her famous ride through Coventry is by Roger of Wendover, who wrote in the beginning of the thirteenth century, or a hundred and fifty years or thereabout after her death. His account of the matter is as follows: "The countess Godiva, who was a great lover of God's mother, longing to free the town of Coventry from the oppression of a heavy toll, often with urgent prayers besought her husband, that from regard to Jesus. Christ and his mother, he would free the town from that service, and from all other heavy burdens; and when the earl sharply rebuked her for foolishly asking what was so much to his damage, and always forbade her evermore to speak to him on the subject; and while she, on the other hand, with a woman's pertinacity, never ceased to exasperate her husband on that matter, he at last made her this answer: 'Mount your horse, and ride naked before all the people, through the market of the town from one end to the other, and on your return you shall have your request.' On which Godiva replied, ' But will you give me permission if I am willing to do it?' 'I will,' said he. Whereupon the 
countess, beloved of God, loosed her hair and let down her tresses, which covered the whole of her body like a veil, and then mounting her horse and attended by two knights, she rode through the market-place without being seen, except her fair legs ; and having completed the journey, she returned with gladness to her astonished husband, and obtained of him what she had asked, for Earl Leofric freed the town of Coventry and its inhabitants from the aforesaid service, and confirmed what he had done by a charter." The modern version adds, in the Laureate's words :

"And one low churl, compact of thankless earth, The fatal byword of all years to come,

Boring a little auger-hole in fear,

Peep'd-but his eyes, before they had their will, Were shrivell'd into darkness in his head,

And dropt before him. So the Powers who wait On noble deeds, cancell'd a sense misus'd."

It is not my business now to prove that the legend is unitrue in fact, or I should insist, first, that its omission by previous writers, who refer both to Leofric and Godgifu and their various good deeds, is strong negative testimony against it ; and I should show, from a calculation made by the late Mr. M. H. Bloxam, and founded on the record of Domesday Book, that the population of Coventry in Leofric's time could scarcely have exceeded three hundred and fifty souls, all in a greater or less degree of servitude, and dwelling probably in wooden hovels each of a single story, with a door, but no window.? Nobody, however, now asserts that Roger of Wendover's narrative is to be taken seriously. What therefore I want to point out in it is, that Godgifu's bargain was, that she should ride naked before all the people. And this is what the historian understands her to have done; for he states that she rode through the

Roger of Wendover's Fiowers of History, sub anno 1057. I quote from Dr. Giles' translation:

' See his Presidential Address to the Warwickshire Naturalists' and Archroologists' Field Club, 1886. 
market-place without being seen, except her fair legs, all the rest of her body being covered by her hair like a veil. He tells us nothing about a proclamation to the inhabitants to keep within doors; and of course Peeping Tom is an impossibility in this version, of the tale.

Coventry has for generations honoured its benefactress by a periodical procession, wherein she is represented by a girl dressed as nearly like the countess on her ride as the manners of the day have permitted. When this procession was first instituted, is unknown. The earliest mention of it seems to be in the year 1678. Its object then was to proclaim the Great Fair, and Lady Godiva was merely an incident in it. The Lansdowne MSS. in the British Museum contain an account of a visit to Coventry by the "captain, lieutenant, and ancient" of the military company of Norwich who travelled in the Midland Counties in August 1634. These tourists describe St. Mary's Hall as adorned at the upper end "with rich hangings, and all about with fayre pictures, one more especially of a noble lady (the Lady Godiva) whose memory they have cause not to forget, for that shee purchas'd and redeem'd their lost infringed liberties and ffreedomes, and obtain'd remission of heavy tributes impos'd upon them by undertaking a hard and unseemly task, w'ch was to ride naked openly at high noone day through the city on a milk white steed, w'ch she willingly performed, according to her lord's strict injunction. It may be very well discussed heere whether his hatred or her love exceeded. Her fayre long hayre did much offend the wanton's glancing eye" In this record we have no additional fact except the mention of "high noone day" as the time of the journey; for the allusion to " the wanton's glancing eye is too vague to be interpreted of Peeping Tom, and the writer does not refer to any commemorative procession. It is possible, therefore, that the carnival times of Charles the Second both begot the procession and tacked Peeping Tom to the legend. But it is more likely that the procession is as old as the fair, which was held 


\section{8}

Peeping Tom and Lady Godiva.

under a charter of Henry the Third, granted in 121\%. Such pageants were not uncommon in municipal life, and were everywhere to the taste of the people. Whether Lady Godiva was a primitive part of it is another question: there seems no improbability in supposing that she was, since the legend was then current. Much more doubt exists as to the episode of Peeping Tom. Looking out of a house at the corner of Smithford Street is a wooden figure called by the name of the notorious tailor. It is in reality a statue of a man in armour, dating no further back than the reign of Henry the Seventh; and it could not have been appropriated to its present purpose until its original design had been forgotten, and the incongruity of its costume passed unrecognised. This is said to have been in 1678, when a figure, identified with the one in question, was put up in Grey Friars Lane by Alderman Owen. 1

It must not be overlooked that there may have been from the first more than one version of the legend, and that a version rejected by, or perhaps unknown to, Roger: of Wendover and the writers who followed him may have always. included the order to the inhabitants to keep within doors, of which Peeping Tóm would seem to be the necessary accompaniment Unfortunately, we have no evidence on this point ; and in such a case it becomes of importance to inquire whether there are any traditions in other places from which we may reason. In the History of Gloucestershire, printed by Samuel Rudder of Cirencester in 1779, we read that the parishioners of St. Briavels, hard by the Forest of Dean, "have a custom of distributing yearly upon Whitsunday, after divine service, pieces of bread and cheese to the congregation at church, to defray the expenses of which every householder in the parish pays a penny to

2 I am indebted to Mr. Samuel Timmins, F.S.A, and also through him to Mr. William George Fretton, F.S.A, for the local information in this paragraph, and for much trouble which they have kindly taken on my behalf. 
the churchwardens; and this is said to be for the privilege of cutting and taking.the wood in Hudnolls. The tradition is that the privilege was obtained of some Earl of Hereford, then lord of the Forest of Dean, at the instance of his lady, upon the same hard terms that Lady Godiva obtained the privileges for the citizens of Coventry."1

I am fortunately able to correct this account by a statement most obligingly made to me by the Rev. W. Taprell Allen, M.A., the vicar of St. Briavels, whence it would appear that the payment was probably made, not to the churchwardens, but to the constable of the castle as Warden of the Forest of Dean. In other respects Rudder seems to have accurately related both custom and tradition, but $\cdot I$ have been unable to obtain any further details.

I am not aware of any other European tradition that will bear comparison with that of Godiva, but Liebrecht relates that he remembers in his youth, about the year 1820 , in a German newspaper, a story according to which a countess frees her husband's subjects from a heavy punishment imposed. by him. She undertakes to walk a certain course clad only in her shift, and she performs it, but clad in a shift. of iron." The condition is here eluded rather than fulfilled; and the point of the story is consequently varied. It would be interesting to have the tale unearthed from the old newspaper, and to know where its scene was laid, and whether it was a genuine piece of folklore.

Eastern tales, however, furnish us repeatedly, with incidents in which a lady parades the streets of a city, and during her progress all folk are bidden to close their shops and withdraw into their houses on pain of death. The example of the Princess. Badroulboudour will occur to every reader of the Arabian Niglts. This, however, is by no means a solitary example. In the story of Kamar AlZaman and the Jeweller's Wife, one of the stories of the

1 Rudder, 307.

- Liebrecht, Zur Volkskutnde, to4. 
Nights rejected on moral grounds by Lane and translated by Burton, a dervish relates that he chanced one Friday to enter the city of Bassorah, and found the streets deserted. The shops were open, but neither man nor woman, girl nor boy, dog nor cat was to be seen. By-and-bye he heard a sound of drums, and hiding himself in a coffee-house, be looked out through a crevice and saw forty pairs of slave girls, with uncovered heads and faces displayed, come walking through the market, and in their midst a lady riding unveiled and adorned with gold and gems. In front of her was a damsel bearing in baldric a great sword with haft of emerald and tassels of jewel-encrusted gold. Pausing close to the dervish, the lady said to her maidens : "I hear a noise of somewhat within yonder shop ; so do ye search it, lest haply there be one hidden there, with intent to enjoy a look at us whilst we have our faces unveiled." Accordingly they searched the shop opposite the coffeehouse, and brought forth a man. At the lady's command the damsel with the sword smote off his head, and leaving the corpse lying on the ground, the procession swept on. It turned out that the lady was the wife of a jeweller to whom the King of Bassorah was desirous of granting. a boon, and at her request the boon obtained was a proclamation commanding that all the townsfolk should every Friday enter the mosques two hours before the hour of prayer, so that none might abide in the town, great or small, unless they were in the mosques or in the houses with the doors locked upon them; but all the shops were to be left open. Then the lady had permission to ride with her slave-women through the heart of the town, and none were to look on her from window or lattice; and everyone whom she found abroad she was at liberty to kill. A similar incident is related in the life of Kurroglu, the robber-poet of Persia, where a beautiful princess passes in state through the bazaars every Friday on her way to the

1 Burton's Arabian Nights, ix, 255. 
mosque, while all the men are banished.1 Here, again, someone was of course found playing the spy.

A version of the.incident, which can be traced much further back in literary form than either of the foregoing, occurs in the Ardshi-Bordshi. This book is a Mongolian recension of a Sanskrit collection of stories concerning Vikramaditya, a monarch who, if he ever lived, seems to have flourished about the beginning of the Christian era. He was celebrated, like Solomon, for his wisdom and his might ; and his name became the centre of a vast accretion of legends. Some of these legends were translated into Mongolian late in the middle ages, and formed a small collection called after Ardshi-Bordshi, the nominal hero. In the story to which I wish to direct attention, a certain king has a daughter bearing the name of Sunshine, of whom he was so jealous that if anyone looked upon her his eyes were put out, and the man who entered her apartments had his legs broken. Naturally, the young lady got tired of being thus immured, and complained to her father that, as she had no opportunity of seeing man or beast, the time hung heavily on her hands; and she begged him to let her-go out on the fifteenth of the month and look about her. The king agreed to this ; but, the sly old rascall. nothing was further from his intention than to gratify his daughter's longing for masculine converse. Wherefore he issued a decree that all objects for sale were to be exposed openly to the view, all cattle to be left indoors, the men and women were to withdraw into their houses and close their doors and windows, and if anyone came forth he should be severely punished. On the appointed day, Sunshine, surrounded by her ladies, and seated in a brand-new chariot, drove through the town, and viewed the merchandise and goods exposed for sale. The king had a minister, named Moon, who could not restrain his curiosity; and he

1 Burton's Supplemental Nights, iii, 570 (Appendix by Mr. W. A. Clouston). Kurroglú flourished in the second half of the seventeenth century. 
peeped at her from a balcony. The princess, as he did so, caught sight of him and mado signs to him, which were interpreted by the penetration of his wife to be an invitation to meet her clandestinely. The wife hardly displayed what most ladies would deem "a proper spirit" in advising compliance; and the consequence of taking that advice would have been serious trouble both to himself and to the princess, had it not been for the ready wit of the two women, who got over the difficulty by contriving an ingenious equivocation not unknown in other stories, by which the princess cleared herself and her lover on oath. ${ }^{2}$

It is true that in these tales.the lady who rides forth is not naked; but to ride openly and unveiled would be thought almost as immodest in countries where strict seclusion is imposed upon women. We have therefora tales including the Peeping Tom incident, from sources unknown in Europe in the seventeenth century, when the Coventry legend had certainly attained its full development. And the incident appears so obvious a corollary to the central thought of Lady Godiva's adventure that it is hardly likely to have required centuries for its evolution. There is, however, an Indian legend from which the incident in question is absent. It is related that the inhabitants of Chamba were under the necessity of digging a canal for irrigation, but when it was dug, owing to the enchantments of an evil spirit, not a drop of water could be got to flow along its course. A magician at last found out that the spell could be dissolved if the beautiful and virtuous young princess of Chamba would consent, to

1 This story is edited by Jijlg in Mongolian and German (Innsbruck, 1867). Miss Busk gives a free adaptation rather than a translation of the German version, in Sages from the Far East, 315. Prof. De Gubernatis, Zoological Mythology, i, 138, of course interprets it as a sun-myth-an interpretation to which the names Sunshine and Moon, and the date of the adventure (the fifteenth of the month), lend themselves. 
traverse a given distance of the plain entirely naked, in full view of the populace, and to lose her head when the journey was accomplished. After much hesitation, her compassion triumphed over her shame, and she undertook the task. But lo! as she advanced, a thick line of young trees arose to right and left, completely hiding her from cynical eyes. And the shady canal is shown to-day by the good people of Chamba as one of the most authentic monuments of their history. ${ }^{1}$

Before leaving the East, let me advert to a curious religious ceremony which may have some bearing upon the legerd under discussion. A potent spell to bring rain was reported as actually practised during the Gorakhpur famine of 1873-4 It consisted of a gang of women stripping themselves perfectly naked, and going out by night to drag the plough across a field. The men were kept carefully out of the way, as it was believed that peeping by them would not only vitiate the spell, but bring trouble on the village.2 - It would not be a long step from this belief to a story in which peeping was alleged to have taken place with disastrous effects, either to the village, or (by favour of the deities intended to be propitiated) to the culprit himself. If we seek further analogue in India, we learn that at the festival of the local goddess in the village of Sertur, in the Southern Mahratta country, the third and fourth days are devated to private offerings. Many women, we are told, on these days walk naked to the temple in fulfilment of vows, "but they were covered with leaves and boughs of trees, and surrounded by their female relations and friends." ${ }^{3}$ The performance of religious rites by women alone, when men are required under heavy penalties to absent themselves, is, indeed, not very uncommon in savage life; and probably a little search would discover in different parts of the world many such as the foregoing. In all

\footnotetext{
1 Tour du Monde, xxi, 342, quoted by Liebrecht, op. cit., 105.

- Panjab Notes and Queries, iii, 4I, 115.

- Jourmal Ethrol. Soc. Londor, N.S., i, 98.
} 
countries ceremonies of a special character are frequently dramatic. They represent, or are believed to represent, actions of the deities in whose honour they are performed. The' Coventry procession is admittedly a representation. of Godgifu's ride. It is not now connected with any professed act of worship, but may it not be the long-descended relic of some such observance as those I have just described? There does not appear from Rudder's account to have been, in his time at least, any pageant at St. Briavels commemorative of the achievement of the lady to whom the parishioners reckoned themselves to owe their privileges, nor have I been able to trace one by local inquiries. But the tradi-: tion is there unmistakably connected with a religious and social rite. The distribution of food on a day of high and holy festival in the church to the congregation, and paid for by a levy upon every householder in the parish, can point to nothing else than a feast of the whole community . as a solemn act of worship. The point requiring elucidation is the intimate relation of this feast with a story apparently so irrelevant as that of the countess's ride. To explain this, we must suppose that the feast was only part-doubtless the concluding part—of a ceremony, and that the former portion was a procession, of which the central figure was identical with that familiar to us at Coventry. But such a procession, terminating in a sacred feast, would have had no meaning if the naked lady represented a creature merely of flesh and blood. It is only explicable on the hypothesis that she was the goddess of a heathen cult, such as Hertha (or Nerthus), whose periodical progress among her subject tribes is described by Tacitus, ${ }^{1}$ and yet survives in the folk-lore of Rugen. Now the historian tells us that Hertha was Mother. Earth, the goddess of the soil, whose yearly celebration would appropriately take place in the spring or early summer. To her the produce of the land

1 Germania, c. 40 ; cf. c. 9. 
would be ascribed; and in her name and by her permission would all agricultural operations be performed. Such a goddess it is who must have been honoured by the ceremonies already noticed in India, and to such a goddess we may readily believe would be ascribed the privilege of cutting wood. It is quite consistent with this that the payment by every household at St Briavels should be made to the warden of the forest, and that it should be spent by him on the goddess's festival. Whether the tolls and burdens vaguely referred to by Roger of Wendover were of an equivalent character we can only surmise.

On the whole, then, I am disposed to think that the legend and procession of Lady Godiva are survivals of a pagan belief and worship located at Coventry; that the legend was concerned with a being awful and mysterious as Dame Berchta, or Hertha herself ; and that the incident of Peeping Tom, in spite of the absence of direct evidence in. its favour, was from the first, or at all events from an early date, part of the story. The evidence upon which these conclusions rest may be shortly recapitulated thus :-

I. The absence of historical foundation for the tradition.

2. The close resemblance between the tradition and other stories which unquestionably deal with heathen goddesses.

3. The equally close analogy between the procession and that described in Eastern stories, which, so far as we know, could not have reached England at the latest period when the procession could possibly have been instituted; and between the procession and certain heathen rites practised not only in the East, but as near home as Germany.

4. The connection between the analogous legend at St. Briavels and the remains of a sacred communal feast that can hardly be anything else than the degraded rempint of a pagan observance.

I have not ventured to refer to the mysteries of Dêmêtêr, equated by many writers with Tacitus' account of the worvol. 2. 


\section{Peeping Tom and Lady Godiva.}

ship of Hertha and another goddess whom he calls Isis. To argue from them, tempting though it is, would necessitate the introduction of too much debatable matter. I have endeavoured to rely on parallels not so readily disputed.

E. SidNey HaRTLAND. 